\title{
Cervical Cancer Control in the Era of HPV Vaccination and Novel Biomarkers
}

\author{
Nicolas Wentzensen ${ }^{a}$ Stefanie J. Klug ${ }^{b}$ \\ aDepartment of Applied Tumor Biology, Institute of Pathology, University of Heidelberg, Heidelberg, and \\ b Institute of Medical Biostatistics, Epidemiology and Informatics (IMBEI), Medical Center of the University of Mainz, \\ Mainz, Germany
}

\begin{abstract}
Key Words
Cervical cancer - Human papillomavirus - Cancer screening • Cytology $\cdot$ Biomarker $\cdot$ Human papillomavirus vaccination
\end{abstract}

\begin{abstract}
Infections with human papillomaviruses (HPV) are a necessary, but not sufficient cause of cervical cancer. Cervical cancer develops over a long time through precursor lesions that can be detected by cytological screening. The majority of these lesions regress spontaneously without treatment. The challenge of cervical cancer screening is to detect the lesions that have a high risk of progression. Since the recently introduced vaccination against HPV cannot provide $100 \%$ protection, cervical cancer screening programs must continue. It is assumed that the reduction of precancers related to vaccination will have a negative impact on the efficiency of current screening programs. Therefore, participation rates need to be increased and current screening modalities should be improved. Several promising biomarkers have been described that might improve cervical cancer screening, but currently, high-quality studies on their efficiency are lacking.
\end{abstract}

Copyright $\odot 2009$ S. Karger AG, Basel (c) 2009 S. Karger AG, Basel

$1015-2008 / 09 / 0762-0082 \$ 26.00 / 0$

Fax +41613061234

E-Mail karger@karger.ch

www.karger.com
Accessible online at: www.karger.com/pat

\section{Epidemiology and Pathogenesis of Cervical Cancer}

Cervical cancer is the second most common cancer among women worldwide. The incidence ranges from $10 / 100,000$ women in industrialized countries to $60 /$ 100,000 women in some developing countries $[1,2]$. The differences in incidence are mainly related to the introduction of cytological screening (exfoliative cytology) in many industrialized countries during the second half of the 20 th century [3].

Human papillomaviruses (HPV) are necessary for the development of cervical cancer [4-9] (fig. 1). There are more than 100 known HPV types, of which 13-15 carcinogenic types (HR-HPV) have the ability to transform genital mucosal cells and trigger the formation of invasive cervical cancer (fig. 1) $[5,10]$. In a recent US-based study on HPV prevalence, HPV was detected in $27 \%$ of women aged between 14 and 59 years (15\% HR-HPV) and in $45 \%$ of women aged $20-24$ years (29\% HR-HPV) [11]. It is estimated that $70 \%$ of all women carry HPV at some point in their lives [12]. Ninety percent of the infections regress spontaneously after a few months without treatment [13]. The risk of development of a precancerous lesion increases with viral persistence [14]. However, more than half of the cervical intraepithelial neoplasias (CIN) regress spontaneously $[15,16]$.

An important step of viral transformation is the overexpression of the viral proteins E6 and E7 from carcino- 
Fig. 1. Progression model of cervical carcinogenesis. Morphologic (top row) and functional (middle row) progression model. Representative biomarkers for the disease stage transitions are indicated.

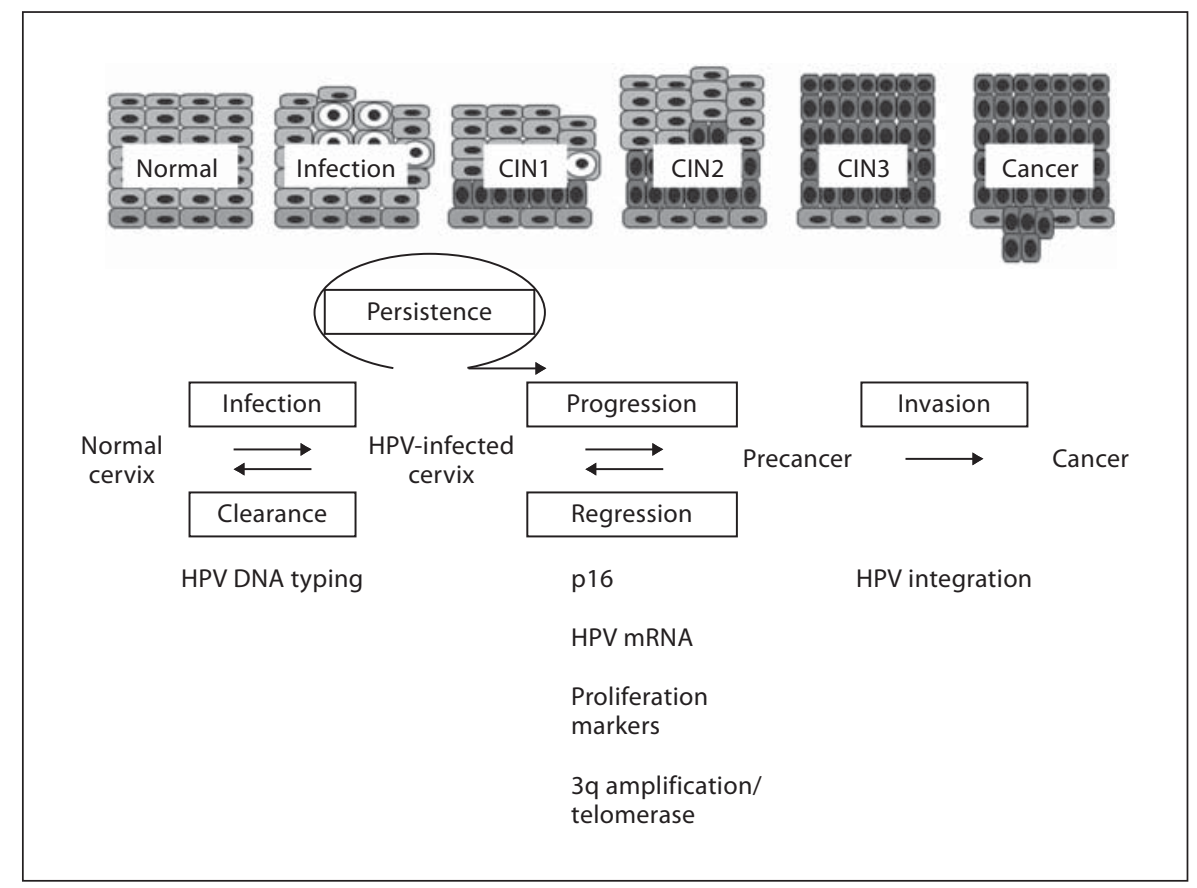

genic types in basal epithelial cells. E6 leads to the degradation of the tumor suppressor protein $\mathrm{p} 53$ and abrogation of apoptosis, while E7 disrupts the binding of $\mathrm{pRb}$ tumor suppressor protein and E2F which leads to uncontrolled cell cycle activation through released E2F $[17,18]$. This results in uncontrolled cell proliferation and chromosomal instability with accumulating DNA damage and may facilitate viral integration $[19,20]$. In the last decade, a functional progression model including the following steps has been established: (1) HPV infection, (2) HPV persistence, (3) transformation with formation of precancerous lesions, and finally (4) invasion to cervical cancer [13] (fig. 1).

\section{Cervical Cancer Screening}

Cervical cancer screening using cytology according to Papanicolaou is based on the identification of precancerous lesions which, if necessary, can be removed curatively [21]. A smear encompassing the whole transformation zone is taken from the endo- and ectocervix, fixed on a microscope slide, stained, and microscopically examined for abnormal cells. The effect of the cytological smear on the incidence of cervical cancer has never been investigated in randomized studies. However, there are many indirect proofs of the efficiency of cytological-based screening. Since the introduction of the cytological smear, the incidence of cervical cancer has decreased by over $60 \%$ in many countries [3, 22-24]. In spite of its success, cervical cancer prevention needs to be improved. Each year, almost 500,000 new cases are detected worldwide. Different studies have shown that $16-24 \%$ of the cancers occur in women who participated in screening at least once in the last $3-5$ years before diagnosis $[25,26]$. As the development of cervical cancer generally takes around 7-10 years, these data suggest a low sensitivity of cytological screening [13]. The reasons mainly lie in insufficient sample material and processing, as well as in erroneous interpretation of cytology specimens [27]. Not only false-negative results, but also those with no clear clinical consequences are problematic, e.g. cases with low-grade changes due to HPV infection (ASCUS/LSIL in the Bethesda classification). Internationally, the sensitivity of a single smear is about 50 $60 \%$. The reliability of the screening is achieved by repeated testing [13]. With frequent testing, the chance of false-positive results increases, leading to unnecessary treatment of lesions which would normally spontaneously regress. The histological examination of conization series has shown that $23-28 \%$ of patients did not have any histological alterations, and that $12-51 \%$ of the conizations were done on the basis of false-positive cytology [28]. The indication for conization should be made with caution as it can be associated with bleeding, infections and complications during subsequent pregnancies [29]. 
The frequent examinations needed for subsequent clarifications and unnecessary treatment of unclear results all add to the expenses presented by cervical cancer screening to the health systems internationally [16].

Currently, in most screening settings, the gold standard of the disease is defined by the histological evaluation of colposcopy-guided biopsy specimens. Clinical management is based on these results, and new screening assays are benchmarked against this gold standard. However, there is a lot of evidence that disease ascertainment based on current colposcopy-biopsy standards is limited. The visual assessment of the cervix in colposcopy has a high interobserver variability and frequently fails in detecting the worst lesion [30]. It has been demonstrated that the sensitivity of colposcopy is not related to the experience of the colposcopist, but to the number of biopsies taken [31]. Even in randomly taken biopsies from normal appearing regions on the cervix, substantial disease was identified [32]. Currently, studies are underway that aim at analyzing better colposcopic procedures and at determining how many biopsies are necessary to improve disease ascertainment. Meanwhile, a combined gold standard including histology and cytology results can improve the situation [33].

\section{Relevance of HPV Vaccination for Cancer Screening}

Two vaccines are available which were demonstrated to protect against the HPV types 16 and 18, with one of them also protecting against HPV 6 and 11 [34]. At present, the available vaccination does not replace cervical cancer screening. First, it will presumably take a long time until a high vaccination rate has been achieved in the general population. Second, there are no long time follow-up data on either the duration of the vaccine protection or on the prevention of cervical cancer. Hence vaccinated women must continue to participate in screening programs. Currently, there are few feasible vaccination strategies for developing countries that carry the largest burden of disease.

In countries with widespread use, the vaccination will have a high impact on cervical cancer screening. From the data of HPV vaccine studies, it can be estimated that the number of lesions associated with HPV 16 and 18 in a vaccinated population will decrease, while lesions associated with other types would be hardly affected [35]. In general, a reduction of the incidence leads to a lower positive predictive value of any test procedure used. There is evidence that cytology will be additionally affected by
HPV vaccination. The distribution of HPV 16 and 18 differs across disease stages $[16,36-38]$. About $70 \%$ of the carcinomas are HPV $16 / 18$ positive, $50 \%$ of mid- to highgrade dysplasia, but only about $20 \%$ of the low-grade abnormalities. In a vaccinated population the total number of abnormal findings will be lower, but the distribution will shift towards low-grade lesions which pose the largest problem diagnostically [35]. As a result of the reduced incidence of high-grade lesions, precancers will be expected less and the ability to detect changes in cytological smears may suffer [35].

\section{Possible Ways of Improving Cytology-Based Cervical Cancer Screening}

An update of the European guidelines on cervical cancer screening was recently published [39]. Among other things, the guidelines recommend well-organized screening programs that incorporate systematic invitation procedures, restrictive quality assurance and regular evaluation. Overall, more women can be reached through a well-organized screening program with systematic invitations to participate. Quality control can be improved within an organized program. In many countries the participation in collaborative assessment experiments and the systematic partial rescreening of specimens is already a mandatory, important part of quality control. Fast rescreening of all normal specimens can effectively reduce false-negative results further [40].

Some quality guidelines require that cytology centers evaluate a certain number of specimens per year $[41,42]$. Currently, there are promising European efforts to harmonize quality assurance and introduce cytological registers [43].

\section{Technical Advancements of Cytology}

Liquid-based cytology is supposed to produce a more uniform cytology specimen that may improve the diagnostic procedures and has been introduced in some countries. While these procedures can be considerably more expensive than conventional cytology, it has not been clearly demonstrated that liquid-based cytology is more sensitive or cost-effective than conventional cytology [44, 45]. It is undisputed that liquid-based cytology can be better standardized than the conventional smear. Additionally, the liquid material can be used for further investigations with biomarkers. 
Table 1. Selection of commercially available biomarkers

\begin{tabular}{|c|c|c|c|c|c|}
\hline $\begin{array}{l}\text { Carcinogenic } \\
\text { HPV DNA }\end{array}$ & $\begin{array}{l}\text { - DNA hybridization } \\
\text { (Hybrid Capture 2) } \\
\text { - PCR (Amplicor) }\end{array}$ & $\begin{array}{l}\text { Clarification of } \\
\text { unclear cytology, } \\
\text { additional test in } \\
\text { primary screening }\end{array}$ & $\begin{array}{l}\text { Excellent, large popu- } \\
\text { lation-based studies, } \\
\text { randomized studies } \\
\text { (Hybrid Capture 2) }\end{array}$ & $\begin{array}{l}\text { Hybrid Capture } 2 \\
\text { intensively tested for } \\
\text { many years, Amplicor } \\
\text { currently undergoing } \\
\text { licensing procedure }\end{array}$ & $\begin{array}{l}\text { Hybrid Capture } \\
2 \text { is FDA- } \\
\text { licensed }\end{array}$ \\
\hline $\begin{array}{l}\text { HPV oncogene } \\
\text { mRNA }\end{array}$ & $\begin{array}{l}\text { RNA test through } \\
\text { nucleic acid amplifi- } \\
\text { cation: } \\
\text { - PreTect Proofer } \\
\text { - Aptima }\end{array}$ & $\begin{array}{l}\text { Identification of high } \\
\text { grade dysplasia, clari- } \\
\text { fication of unclear } \\
\text { cytology }\end{array}$ & $\begin{array}{l}\text { Some clinical studies } \\
\text { published, popula- } \\
\text { tion-based studies } \\
\text { running }\end{array}$ & $\begin{array}{l}2 \text { different methods } \\
\text { certified, PreTect } \\
\text { Proofer available for } \\
\text { some time now, } \\
\text { Aptima about to be } \\
\text { introduced }\end{array}$ & \\
\hline $\begin{array}{l}\text { HPV capsid } \\
\text { protein }\end{array}$ & L1 Protein test & $\begin{array}{l}\text { Clarification of } \\
\text { unclear cytology }\end{array}$ & $\begin{array}{l}\text { Hardly any data } \\
\text { published }\end{array}$ & $\begin{array}{l}\text { Certified kits for } \\
\text { broad-range high risk } \\
\text { - HPV L1 }\end{array}$ & $\begin{array}{l}\text { Does not replace } \\
\text { an HPV DNA } \\
\text { test }\end{array}$ \\
\hline p16 & $\begin{array}{l}\text { Protein test } \\
\text { CINtec histology, } \\
\text { CINtec cytology }\end{array}$ & $\begin{array}{l}\text { Identification of high- } \\
\text { grade dysplasia clari- } \\
\text { fication of unclear } \\
\text { cytology, primary } \\
\text { screening? }\end{array}$ & $\begin{array}{l}\text { Many clinical studies } \\
\text { published, population } \\
\text { based-studies } \\
\text { running }\end{array}$ & $\begin{array}{l}\text { Certified tests avail- } \\
\text { able for a few years }\end{array}$ & \\
\hline $\begin{array}{l}\text { Replication } \\
\text { markers }\end{array}$ & $\begin{array}{l}\text { Protein test } \\
\text { ProExC }\end{array}$ & $\begin{array}{l}\text { Identification of high- } \\
\text { grade dysplasia }\end{array}$ & $\begin{array}{l}\text { Hardly any data } \\
\text { published }\end{array}$ & $\begin{array}{l}\text { Certified methods, } \\
\text { recently introduced }\end{array}$ & \\
\hline
\end{tabular}

\section{Application of Biomarkers in Cervical Cancer Screening}

\section{HPV DNA}

A variety of biomarkers to investigate cervical lesions are available (tables 1,2). The HPV test has a high sensitivity for the detection of precancerous lesions and invasive cancer (above 90\%). However, an HPV DNA test cannot distinguish between a transient infection and an invasive carcinoma. As the peak of HPV infection in young women is below the age of 30 years, a single HPV test in this age group only has limited significance [46-48].

The Hybrid Capture 2 test (HC2) is currently the only HPV test licensed by the FDA (United States Food and Drug Administration). This test shows whether 1 of 13 high-risk types is present, but does not give information on individual HPV types.

The risk of developing a precancerous lesion is between 10 and $15 \%$ for an infection with HPV 16 or 18, while it is below 3\% for all other high-risk types combined [49]. Thus, a better risk stratification could be achieved by using a type-specific test. Individual genotyping procedures are currently not sufficiently validated, expensive, and not common in routine laboratories. Brink et al. [50] provide an overview of the different HPV testing options.

The HC2 HPV test was initially evaluated as a management option for inconclusive cytology results. In a US study it was shown that the HPV test allows a more effective triage of ASCUS cytology than a repeated cytological examination [51]. These results were confirmed in a meta-analysis [52].

In the meantime large randomized studies on the use of HPV testing in primary screening programs have been conducted and were recently published [53-55]. The studies showed that $50-70 \%$ more precancers can be diagnosed initially when HPV testing is incorporated in primary screening. Since a negative HPV test can exclude the risk of disease in the subsequent years with high cer- 
Table 2. Selection of noncommercial test methods

\begin{tabular}{llll}
\hline Marker & Test format & Application area & Data situation \\
\hline $\begin{array}{l}\text { Proliferation } \\
\text { markers MYC, ki67 }\end{array}$ & Protein test, IHC & $\begin{array}{l}\text { Identification of } \\
\text { high-grade dysplasia }\end{array}$ & $\begin{array}{l}\text { Some pilot } \\
\text { studies }\end{array}$ \\
\hline $\begin{array}{l}\text { Telomerase, 3q } \\
\text { amplification }\end{array}$ & $\begin{array}{l}\text { In situ hybrid- } \\
\text { ization }\end{array}$ & $\begin{array}{l}\text { Identification of } \\
\text { high-grade dysplasia }\end{array}$ & $\begin{array}{l}\text { Some pilot } \\
\text { studies }\end{array}$ \\
\hline Aneuploidy & Flow cytometry & $\begin{array}{l}\text { Identification of } \\
\text { high-grade dysplasia }\end{array}$ & Few studies \\
\hline or cytology & (RT) PCR, & $\begin{array}{l}\text { Aftercare, clonality } \\
\text { test }\end{array}$ & $\begin{array}{l}\text { Functional } \\
\text { analyses, few } \\
\text { studies }\end{array}$ \\
\hline
\end{tabular}

tainty, it is possible to run screening intervals of 3-5 years without compromising safety. Apart from that, an HPVbased screening offers the possibility of extracting specimens during self-examination at home, a fact which could lead to increased screening participation rates [56].

\section{Biomarkers for HPV-Associated Transformation}

The decisive step in carcinogenesis after HPV infection is the transformation of basal epithelial cells, initiated through the deregulated expression of the viral oncogenes E6 and E7 [17, 18]. A number of markers for this step are currently being analyzed, among them high-risk HPV mRNA, classic proliferation markers (ki67, MYC, telomerase, MCM2, Top2A), as well as p16, an indirect marker for HPV oncogene activity. Other biomarkers show the effects of chromosomal instability caused by the transformation, among them LOH markers (loss of heterozygosity), methylation markers, aneuplody and HPV integration [57, 58]. The detection of the viral capsid protein L1 aims at differentiating innocuous productive infections from transforming infections [59]. A selection of biomarkers is shown in tables 1 and 2. Currently available data on most of the biomarkers presented does not warrant their routine use yet. However, results of high quality studies on the use of new biomarkers in cervical cancer screening are expected in the near future.

\section{HPV RNA}

Oncogenic HPV mRNA detection is supposed to be more specific for the transformation of epithelial cells than detection of HPV DNA [17]. Currently, there are two commercial tests for HPV mRNA. RNA proofer detects HPV oncogene mRNAs of five frequent HPV types, while the Aptima test detects mRNAs of 13 carcinogenic types. Results of studies on the RNA proofer test showed that it is more specific for high-grade lesions than an HPV DNA test, but has a lower sensitivity [60-63].

\section{Proliferation Markers}

Proliferation markers like ki67, MYC, cycline, MAP kinase pathway markers, and survivin were tested in many small studies [64-73]. Recently, an assay which shows the overexpression of proliferation-associated proteins in histology and cytology has been introduced to the market (ProExC), but up to now there has not been much data available on the clinical relevance of this test [74].

The chromosome amplification 3q, which can be associated with increased telomerase activity, is frequently found in cervical cancer and precancerous lesions and might be a further interesting marker $[75,76]$.

\section{p16}

The overexpression of p16 is a direct result of cell cycle aberrations induced by HPV oncogenes, irrespective of the initiating HPV type [77, 78]. The CINtec tests are based on the histological or cytological detection of p16. Cervical carcinomas and precancers of the cervix are specifically stained with p16 in immunohistochemical studies [79]. The evaluation of the histological specimens of the cervix can be improved by p16 staining [80-82]; many pathologists use p16 to clarify difficult cases. In cytology, staining with p16 can improve the identification of suspicious cells on cytological slides [83]. p16 cytology has been successfully used as a triage marker for ASCUS and LSIL cytology results $[84,85]$. Initial data on an ELISA-based p16 test suggest that it could be used as a simple test to evaluate the risk of cervical precancer $[86,87]$.

Many other biomarker candidates apart from those mentioned here have been described; however, for most of them hardly any clinical or epidemiological data are available [58]. 


\section{Conclusion}

Despite the introduction of vaccines against HPV, it is still a long way to go before a successful control of cervical cancer is achieved globally. The available vaccines do not protect against all tumor-relevant HPV types and it will probably take a long time before a broad vaccine coverage is achieved worldwide. Therefore it is important to continue cervical cancer screening for vaccinated as well as nonvaccinated women. The negative effects of HPV vaccination on the performance of cytology will require a reassessment and modification of current screening programs, especially regarding effectiveness, efficiency and quality control. There are a number of possible starting points how screening can be adapted in a combination with HPV vaccination. It would be beneficial to propagate organized screening programs for vaccinated and nonvaccinated women, which entails systematic documentation of vaccination and screening procedures as well as their results. Existing and new methods have to be strengthened by standardizing the procedures and quality assurance processes. Where appropriate, new biomarkers can be used to support or replace existing ones. Many of the new test methods are complex and can only be used in specialized laboratories. At present, various ways of reorganizing gynecological cancer screening, mostly based on multistage concepts, are being discussed internationally (e.g. a more sensitive primary test followed by a specific clarification test). Currently, sufficient data for novel approaches in primary screening is available only for HPV testing. Apart from modifying screening procedures, improvement in cervical disease ascertainment is necessary. Revised colposcopy-biopsy protocols with multiple biopsy sampling are currently evaluated.

In future cervical cancer prevention strategies, the aim is to achieve a valid risk estimation using the best methods available. Invitation to participation in screening programs as well as clinical procedures should be oriented on the individual risk profile based on different test results [88]. New biomarkers and tests should only be used after they have been thoroughly validated in highquality studies.

\section{Acknowledgment}

We thank Florence Samkange-Zeeb for assistance in preparing the manuscript.

\section{References}

1 Parkin DM, Bray F: The burden of HPV-related cancers. Vaccine 2006;24(suppl 3):S11S25.

2 Waggoner SE: Cervical cancer. Lancet 2003; $361: 2217-2225$

-3 Gustafsson L, Ponten J, Zack M, Adami HO: International incidence rates of invasive cervical cancer after introduction of cytological screening. Cancer Causes Control 1997;8 755-763.

4 Munoz N, Bosch FX, de Sanjosé S, Tafur L, Izarzugaza I, Gili M, Viladiu P, Navarro C, Martos C, Ascunce N: The causal link between human papillomavirus and invasive cervical cancer: a population-based casecontrol study in Colombia and Spain. Int Cancer 1992;52:743-749.

5 Munoz N, Bosch FX, de Sanjosé S, Herrero R, Castellsague X, Shah KV, Snijders PJ, Meijer CJ: Epidemiologic classification of human papillomavirus types associated with cervical cancer. N Engl J Med 2003;348:518527.

-6 Schiffman MH, Bauer HM, Hoover RN, Glass AG, Cadell DM, Rush BB, Scott DR, Sherman ME, Kurman RJ, Wacholder S: Epidemiologic evidence showing that human papillomavirus infection causes most cervical intraepithelial neoplasia. J Natl Cancer Inst 1993;85:958-964.
7 Walboomers JM, Jacobs MV, Manos MM, Bosch FX, Kummer JA, Shah KV, Snijders PJ, Peto J, Meijer CJ, Munoz N: Human papillomavirus is a necessary cause of invasive cervical cancer worldwide. J Pathol 1999; 189:12-19.

8 zur Hausen H: Disrupted dichotomous intracellular control of human papillomavirus infection in cancer of the cervix. Lancet 1994;343:955-957.

9 zur Hausen H: Papillomaviruses and cancer: from basic studies to clinical application. Nat Rev Cancer 2002;2:342-350.

10 Cogliano V, Baan R, Straif K, Grosse Y, Secretan B, El Ghissassi F: Carcinogenicity of human papillomaviruses. Lancet Oncol 2005;6:204

11 Dunne EF, Unger ER, Sternberg M, McQuillan G, Swan DC, Patel SS, Markowitz LE: Prevalence of HPV infection among females in the United States. JAMA 2007;297:813819.

12 Syrjanen K, Hakama M, Saarikoski S, Vayrynen M, Yliskoski M, Syrjanen S, Kataja V, Castren O: Prevalence, incidence, and estimated life-time risk of cervical human papillomavirus infections in a nonselected Finnish female population. Sex Transm Dis 1990;17:15-19.
13 Schiffman M, Castle PE, Jeronimo J, Rodriguez AC, Wacholder S: Human papillomavirus and cervical cancer. Lancet 2007;370: 890-907.

14 Schlecht NF, Kulaga S, Robitaille J, Ferreira S, Santos M, Miyamura RA, Duarte-Franco E, Rohan TE, Ferenczy A, Villa LL, Franco EL: Persistent human papillomavirus infection as a predictor of cervical intraepithelial neoplasia. JAMA 2001;286:3106-3114.

15 Ostor AG: Natural history of cervical in traepithelial neoplasia: a critical review. Int J Gynecol Pathol 1993;12:186-192.

16 Schiffman M: Integration of human papillomavirus vaccination, cytology, and human papillomavirus testing. Cancer 2007;111: 145-153.

17 Doorbar J: Papillomavirus life cycle organization and biomarker selection. Dis Markers 2007;23:297-313

18 von Knebel DM: New markers for cervical dysplasia to visualise the genomic chaos created by aberrant oncogenic papillomavirus infections. Eur J Cancer 2002;38:22292242.

19 Duensing S, Munger K: Centrosome abnormalities, genomic instability and carcinogenic progression. Biochim Biophys Acta 2001;1471:M81-M88. 
20 Wentzensen N, Vinokurova S, von Knebel DM: Systematic review of genomic integration sites of human papillomavirus genomes in epithelial dysplasia and invasive cancer of the female lower genital tract. Cancer Res 2004;64:3878-3884.

-21 Papanicolaou GN: A survey of the actualities and potentialities of exfoliative cytology in cancer diagnosis. Ann Intern Med 1949;31: 661-674.

$\$ 22$ Day NE: Effect of cervical cancer screening in Scandinavia. Obstet Gynecol 1984;63: 714-718.

-23 Franco EL, Duarte-Franco E, Ferenczy A: Cervical cancer: epidemiology, prevention and the role of human papillomavirus infection. CMAJ 2001;164:1017-1025.

24 Quinn M, Babb P, Jones J, Allen E: Effect of screening on incidence of and mortality from cancer of cervix in England: evaluation based on routinely collected statistics. BMJ 1999;318:904-908.

-25 Janerich DT, Hadjimichael O, Schwartz PE, Lowell DM, Meigs JW, Merino MJ, Flannery JT, Polednak AP: The screening histories of women with invasive cervical cancer, Connecticut. Am J Public Health 1995;85:791794.

-26 Sasieni PD, Cuzick J, Lynch-Farmery E: Estimating the efficacy of screening by auditing smear histories of women with and without cervical cancer. The National Co-Ordinating Network for Cervical Screening Working Group. Br J Cancer 1996;73:1001-1005.

-27 McCrory DC, Matchar DB, Bastian L, Datta S, Hasselblad V, Hickey J, Myers E, Nanda K: Evaluation of cervical cytology. Evid Rep Technol Assess (Summ) 1999;1-6.

>28 Golbang P, Scurry J, de Jong S, McKenzie D, Planner R, Pyman J, Davoren R: Investigation of 100 consecutive negative cone biopsies. Br J Obstet Gynaecol 1997;104:100-104.

-29 Kyrgiou M, Koliopoulos G, Martin-Hirsch P, Arbyn M, Prendiville W, Paraskevaidis E: Obstetric outcomes after conservative treatment for intraepithelial or early invasive cervical lesions: systematic review and metaanalysis. Lancet 2006;367:489-498.

30 Jeronimo J, Schiffman M: Colposcopy at a crossroads. Am J Obstet Gynecol 2006;195: 349-353.

-31 Gage JC, Hanson VW, Abbey K, Dippery S, Gardner S, Kubota J, Schiffman M, Solomon D, Jeronimo J: Number of cervical biopsies and sensitivity of colposcopy. Obstet Gynecol 2006;108:264-272.

32 Pretorius RG, Zhang WH, Belinson JL, Huang MN, Wu LY, Zhang X, Qiao YL: Colposcopically directed biopsy, random cervical biopsy, and endocervical curettage in the diagnosis of cervical intraepithelial neoplasia II or worse. Am J Obstet Gynecol 2004; 191:430-434.
33 Wentzensen N, Schiffman M, Dunn ST, Zuna RE, Walker J, Allen RA, Zhang R, Sherman ME, Wacholder S, Jeronimo J, Gold MA, Wang SS: Grading the severity of cervical neoplasia based on combined histopathology, cytopathology, and HPV genotype distribution among 1700 women referred to colposcopy in Oklahoma. Int J Cancer 2009; 124:964-969.

34 Schiller JT, Lowy DR: Prospects for cervical cancer prevention by human papillomavirus vaccination. Cancer Res 2006;66:1022910232.

35 Franco EL, Cuzick J: Cervical cancer screening following prophylactic human papillomavirus vaccination. Vaccine 2008;26(suppl 1):A16-A23.

36 Clifford G, Franceschi S, Diaz M, Munoz N, Villa LL: HPV type-distribution in women with and without cervical neoplastic diseases. Vaccine 2006;24(suppl 3):S26-S34.

-37 Franco EL, Cuzick J, Hildesheim A, de Sanjose S: Issues in planning cervical cancer screening in the era of HPV vaccination. Vaccine 2006;24(suppl 3):S171-S177.

38 Wright TC Jr, Schiffman M, Solomon D, Cox JT, Garcia F, Goldie S, Hatch K, Noller KL, Roach N, Runowicz C, Saslow D: Interim guidance for the use of human papillomavirus DNA testing as an adjunct to cervical cytology for screening. Obstet Gynecol 2004; 103:304-309.

39 Arbyn M: European Guidelines for Quality Assurance in Cervical Cancer Screening. 2008. http://bookshop.europa.eu/eubookshop/FileCache/PUBPDF/ND7007117ENC/ ND7007117ENC_002.pdf

-40 Dudding N, Hewer EM, Lancucki L, Rice S: Rapid screening: a comparative study. Cytopathology 2001;12:235-248.

41 American College of Pathologists: Commission on Laboratory Accreditation. Cytopathology Checklist. http://www.cap.org/apps/ cap.portal 2006.

42 SAC-Singlas Accreditation Scheme for Laboratories. MED002 Specific Criteria for Cytopathology Section. http://www.sac-accreditation.gov.sg/index.asp 2007.

43 Wiener HG, Klinkhamer P, Schenck U, Arbyn M, Bulten J, Bergeron C, Herbert A: European guidelines for quality assurance in cervical cancer screening: recommendations for cytology laboratories. Cytopathology 2007; 18:67-78.

-44 Davey E, Barratt A, Irwig L, Chan SF, Macaskill P, Mannes P, Saville AM: Effect of study design and quality on unsatisfactory rates, cytology classifications, and accuracy in liquid-based versus conventional cervical cytology: a systematic review. Lancet 2006; 367:122-132.

45 Karnon J, Peters J, Platt J, Chilcott J, McGoogan E, Brewer N: Liquid-based cytology in cervical screening: an updated rapid and systematic review and economic analysis. Health Technol Assess 2004;8:iii,1-iii,78.
46 Cuzick J, Szarewski A, Cubie H, Hulman G, Kitchener H, Luesley D, McGoogan E, Menon U, Terry G, Edwards R, Brooks C, Desai M, Gie C, Ho L, Jacobs I, Pickles C, Sasieni P: Management of women who test positive for high-risk types of human papillomavirus: the HART study. Lancet 2003;362:1871-1876.

-47 Ronco G, Segnan N, Giorgi-Rossi P, Zappa M, Casadei GP, Carozzi F, Dalla PP, Del Mistro A, Folicaldi S, Gillio-Tos A, Nardo G, Naldoni C, Schincaglia P, Zorzi M, Confortini M, Cuzick J: Human papillomavirus testing and liquid-based cytology: results at recruitment from the new technologies for cervical cancer randomized controlled trial. J Natl Cancer Inst 2006;98:765-774.

48 Ronco G, Giorgi-Rossi P, Carozzi F, Dalla PP, Del Mistro A, De Marco L, De Lillo M, Naldoni C, Pierotti P, Rizzolo R, Segnan N, Schincaglia $\mathrm{P}$, Zorzi M, Confortini $\mathrm{M}, \mathrm{Cu}-$ zick J: Human papillomavirus testing and liquid-based cytology in primary screening of women younger than 35 years: results at recruitment for a randomised controlled trial. Lancet Oncol 2006;7:547-555.

49 Khan MJ, Castle PE, Lorincz AT, Wacholder S, Sherman M, Scott DR, Rush BB, Glass AG, Schiffman M: The elevated 10-year risk of cervical precancer and cancer in women with human papillomavirus (HPV) type 16 or 18 and the possible utility of type-specific $\mathrm{HPV}$ testing in clinical practice. J Natl Cancer Inst 2005;97:1072-1079.

50 Brink AA, Snijders PJ, Meijer CJ: HPV detection methods. Dis Markers 2007;23:273-281.

51 Schiffman M, Solomon D: Findings to date from the ASCUS-LSIL Triage Study (ALTS). Arch Pathol Lab Med 2003;127:946-949.

-52 Arbyn M, Buntinx F, van Ranst M, Paraskevaidis E, Martin-Hirsch P, Dillner J: Virologic versus cytologic triage of women with equivocal Pap smears: a meta-analysis of the accuracy to detect high-grade intraepithelial neoplasia. J Natl Cancer Inst 2004;96:280-293.

53 Bulkmans NW, Rozendaal L, Snijders PJ, Voorhorst FJ, Boeke AJ, Zandwijken GR, van Kemenade FJ, Verheijen RH, Groningen K, Boon ME, Keuning HJ, van Balleqooijen M, van den Brule AJ, Meijer CJ: POBASCAM, a population-based randomized controlled trial for implementation of high-risk HPV testing in cervical screening: design, methods and baseline data of 44,102 women. Int J Cancer 2004;110:94-101.

54 Mayrand MH, Duarte-Franco E, Rodrigues I, Walter SD, Hanley J, Ferenczy A, Ratnam S, Coutlee F, Franco EL: Human papillomavirus DNA versus Papanicolaou screening tests for cervical cancer. N Engl J Med 2007; 357:1579-1588.

55 Naucler P, Ryd W, Tornberg S, Strand A, Wadell G, Elfgren K, Radberg T, Strander B, Forslund O, Hansson BG, Rylander E, Dillner J: Human papillomavirus and Papanicolaou tests to screen for cervical cancer. $\mathrm{N}$ Engl J Med 2007;357:1589-1597. 
56 Bais AG, van Kemenade FJ, Berkhof J, Verheijen RH, Snijders PJ, Voorhorst F, Babovic $M$, van Balleqooijen $M$, Helmerhorst TJ, Meijer CJ: Human papillomavirus testing on self-sampled cervicovaginal brushes: an effective alternative to protect nonresponders in cervical screening programs. Int J Cancer 2007;120:1505-1510.

57 von Knebel-Doeberitz M, Syrjanen KJ: Molecular markers: how to apply in practice. Gynecol Oncol 2006;103:18-20.

58 Wentzensen N, von Knebel DM: Biomarkers in cervical cancer screening. Dis Markers 2007;23:315-330.

-59 Griesser H, Sander H, Hilfrich R, Moser B, Schenck U: Correlation of immunochemical detection of HPV L1 capsid protein in pap smears with regression of high-risk HPV positive mild/moderate dysplasia. Anal Quant Cytol Histol 2004;26:241-245.

-60 Lie AK, Risberg B, Borge B, Sandstad B, Delabie J, Rimala R, Onsrud M, Thoresen S: DNA- versus RNA-based methods for human papillomavirus detection in cervical neoplasia. Gynecol Oncol 2005;97:908-915.

61 Molden T, Kraus I, Karlsen F, Skomedal H, Nygard JF, Hagmar B: Comparison of human papillomavirus messenger RNA and DNA detection: a cross-sectional study of 4,136 women $>30$ years of age with a 2 -year follow-up of high-grade squamous intraepithelial lesion. Cancer Epidemiol Biomarkers Prev 2005;14:367-372.

-62 Molden T, Nygard JF, Kraus I, Karlsen F, Nygard M, Skare GB, Skomedal H, Thoresen SO, Hagmar B: Predicting CIN2+ when detecting HPV mRNA and DNA by PreTect HPV-proofer and consensus PCR: a 2-year follow-up of women with ASCUS or LSIL Pap smear. Int J Cancer 2005;114:973-976.

63 Molden T, Kraus I, Karlsen F, Skomedal H, Hagmar B: Human papillomavirus E6/E7 mRNA expression in women younger than 30 years of age. Gynecol Oncol 2006;100:95100.

-64 Abba MC, Laguens RM, Dulout FN, Golijow CD: The c-myc activation in cervical carcinomas and HPV 16 infections. Mutat Res 2004;557:151-158.

- 65 Branca M, Ciotti M, Santini D, Bonito LD, Benedetto A, Giorgi C, Paba P, Favalli C, Costa S, Agarossi A, Alderisio M, Syrjanen $\mathrm{K}$ : Activation of the ERK/MAP kinase pathway in cervical intraepithelial neoplasia is related to grade of the lesion but not to highrisk human papillomavirus, virus clearance, or prognosis in cervical cancer. Am J Clin Pathol 2004;122:902-911.

-66 Branca M, Giorgi C, Santini D, Di Bonito L, Ciotti M, Costa S, Benedetto A, Casolati EA, Favalli C, Paba P, Di Bonito P, Mariani L, Syrjanen S, Bonifacio D, Accardi L, Zanconati F, Syrjanen K: Survivin as a marker of cervical intraepithelial neoplasia and highrisk human papillomavirus and a predictor of virus clearance and prognosis in cervical cancer. Am J Clin Pathol 2005;124:113-121.
67 Branca M, Giorgi C, Ciotti M, Santini D, Di Bonito L, Costa S, Benedetto A, Bonifacio D, Di Bonito P, Paba P, Accardi L, Mariani L, Ruutu M, Syrjanen SM, Favalli C, Syrjanen $\mathrm{K}$ : Over-expression of topoisomerase IIalpha is related to the grade of cervical intraepithelial neoplasia (CIN) and high-risk human papillomavirus (HPV), but does not predict prognosis in cervical cancer or HPV clearance after cone treatment. Int J Gynecol Pathol 2006;25:383-392.

68 El Ghobashy AA, Shaaban AM, Herod J, Innes J, Prime W, Herrington CS: Overexpression of cyclins A and B as markers of neoplastic glandular lesions of the cervix. Gynecol Oncol 2004;92:628-634.

69 Goel MM, Mehrotra A, Singh U, Gupta HP, Misra JS: MIB-1 and PCNA immunostaining as a diagnostic adjunct to cervical Pap smear. Diagn Cytopathol 2005;33:15-19.

70 Golijow CD, Abba MC, Mouron SA, Gomez MA, Dulout FN: c-myc gene amplification detected in preinvasive intraepithelial cervical lesions. Int J Gynecol Cancer 2001;11: 462-465.

71 Keating JT, Cviko A, Riethdorf S, Riethdorf L, Quade BJ, Sun D, Duensing S, Sheets EE, Munger K, Crum CP: Ki-67, cyclin E, and p16INK4 are complimentary surrogate biomarkers for human papilloma virus-related cervical neoplasia. Am J Surg Pathol 2001;25: 884-891.

72 Syrjanen KJ: Immunohistochemistry in assessment of molecular pathogenesis of cervical carcinogenesis. Eur J Gynaecol Oncol 2005;26:5-19.

73 Weaver EJ, Kovatich AJ, Bibbo M: Cyclin E expression and early cervical neoplasia in ThinPrep specimens. A feasibility study. Acta Cytol 2000;44:301-304.

74 Shroyer KR, Homer P, Heinz D, Singh M: Validation of a novel immunocytochemical assay for topoisomerase II-alpha and minichromosome maintenance protein 2 expression in cervical cytology. Cancer 2006;108: 324-330.

75 Heselmeyer-Haddad K, Sommerfeld K, White NM, Chaudhri N, Morrison LE, Palanisamy N, Wang ZY, Auer G, Steinberg W, Ried T: Genomic amplification of the human telomerase gene (TERC) in pap smears predicts the development of cervical cancer. Am J Pathol 2005;166:1229-1238.

76 Heselmeyer K, Schrock E, du Manoir S, Blegen $\mathrm{H}$, Shah K, Steinbeck R, Auer G, Ried T: Gain of chromosome $3 \mathrm{q}$ defines the transition from severe dysplasia to invasive carcinoma of the uterine cervix. Proc Natl Acad Sci USA 1996;93:479-484.

77 Khleif SN, DeGregori J, Yee CL, Otterson GA, Kaye FJ, Nevins JR, Howley PM: Inhibition of cyclin D-CDK4/CDK6 activity is associated with an E2F-mediated induction of cyclin kinase inhibitor activity. Proc Natl Acad Sci USA 1996;93:4350-4354.
78 Sano T, Oyama T, Kashiwabara K, Fukuda T, Nakajima T: Expression status of p16 protein is associated with human papillomavirus oncogenic potential in cervical and genital lesions. Am J Pathol 1998;153:1741-1748.

79 Klaes R, Friedrich T, Spitkovsky D, Ridder R, Rudy W, Petry U, Dallenbach-Hellweg G, Schmidt D, von Knebel DM: Overexpression of p16(INK4A) as a specific marker for dysplastic and neoplastic epithelial cells of the cervix uteri. Int J Cancer 2001;92:276-284.

80 Horn LC, Reichert A, Oster A, Arndal SF, Trunk MJ, Ridder R, Rassmussen OF, Bjelkenkrantz K, Christiansen P, Eck M, Lorey T, Skovlund VR, Ruediger T, Schneider V, Schmidt D: Immunostaining for p16INK4a used as a conjunctive tool improves interobserver agreement of the histologic diagnosis of cervical intraepithelial neoplasia. Am J Surg Pathol 2008;32:502-512.

-81 Klaes R, Benner A, Friedrich T, Ridder R, Herrington S, Jenkins D, Kurman RJ, Schmidt D, Stoler M, von Knebel DM: p16INK4a immunohistochemistry improves interobserver agreement in the diagnosis of cervical intraepithelial neoplasia. Am J Surg Pathol 2002;26:1389-1399.

82 Zhang Q, Kuhn L, Denny LA, De Souza M, Taylor S, Wright TC Jr: Impact of utilizing p16INK4A immunohistochemistry on estimated performance of three cervical cancer screening tests. Int J Cancer 2007;120:351356.

83 Dehn D, Torkko KC, Shroyer KR: Human papillomavirus testing and molecular markers of cervical dysplasia and carcinoma. Cancer 2007;111:1-14.

84 Wentzensen N, Bergeron C, Cas F, Vinokurova S, von Knebel DM: Triage of women with ASCUS and LSIL cytology: use of qualitative assessment of p16INK4a positive cells to identify patients with high-grade cervical intraepithelial neoplasia. Cancer 2007;111: $58-66$.

85 Ziemke P: Immunocytochemistry (p16INK4a) as an additional examination for cytological specimens Class III D (Munich Classification II) (in German). Zentralbl Gynaekol 2005;127:140-145.

86 Mao C, Balasubramanian A, Yu M, Kiviat N, Ridder R, Reichert A, Herkert M, von Knebel DM, Koutsky LA: Evaluation of a new p16(INK4A) ELISA test and a high-risk HPV DNA test for cervical cancer screening: results from proof-of-concept study. Int J Cancer 2007;120:2435-2438.

87 Wentzensen N, Hampl M, Herkert M, Reichert A, Trunk MJ, Poremba C, Ridder R, von Knebel DM: Identification of high-grade cervical dysplasia by the detection of p16INK4a in cell lysates obtained from cervical samples. Cancer 2006;107:2307-2313.

$\checkmark 88$ Castle PE, Sideri M, Jeronimo J, Solomon D, Schiffman M: Risk assessment to guide the prevention of cervical cancer. Am J Obstet Gynecol 2007;197:356. 